\title{
ИЗУЧЕНИЕ АНТИАРИТМИЧЕСКИХ СВОЙСТВ КАРВЕДИЛОЛА У БОЛЬНЫХ САХАРНЫМ ДИАБЕТОМ 2 ТИПА
}

\author{
Крутиков Е.С., Цветков В. А., Чистякова С. И. \\ Медицинская академия имени С.И. Георгиевского (структурное подразделение) \\ ФГАОУ ВО «Крымский федеральный университет имени В.И. Вернадского», Симферополь.
}

ЦЕЛЬ: изучение эффективности карведилола в лечении нарушений сердечного ритма у больных сахарным диабетом 2-го типа.

МАТЕРИАЛЫ И МЕТОДЫ: в исследование были включены 102 человека с сахарным диабетом (СД) 2-го типа и умеренной артериальной гипертензией (АГ), у которых было диагностировано сочетание суправентрикулярных и вентрикулярных нарушений сердечного ритма. Данным пациентам с сочетанными аритмиями к базисной антигипертензивной терапии, был добавлен неселективный $\beta$-адреноблокатор

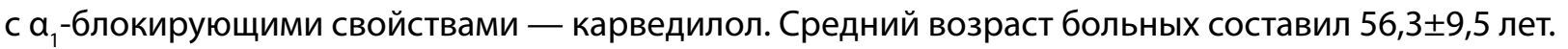

Всем участникам исследования было проведено суточное мониторирование ЭКГ с применением аппаратно-программного комплекса Поли-Спектр-СМ (Россия) до начала лечения и через 4 недели терапии.

PЕзУЛЬТАТЫ: больным был назначен карведилол в начальной дозе 6,25 мг 2 раза в сутки с последующим титрованием при хорошей переносимости до 25 мг 2 раза в сутки. Средняя суточная доза карведи-

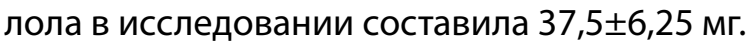

Наиболее распространенным нарушением сердечного ритма у больных СД является синусовая тахикардия. Полученные результаты исследования показали, что терапия карведилолом в течение 4-х недель снижает среднесуточную частоту сердечных сокращений (ЧСС) с $82(74 ; 92)$ до $69(64 ; 83)$ в мин. (р<0,05) и нормализует показатель ее циркадного профиля, увеличивая его с $1,17(1,15 ; 1,24)$ до $1,24(1,18 ; 1,3)$ $(p<0,05)$.

Прием карведилола сопровождался уменьшением частоты единичных, парных и групповых суправентрикулярных экстрасистол на 50\%, а также снижал в 3 раза частоту пароксизмальной формы фибрилляции предсердий, являющейся наиболее опасным суправентрикулярным нарушением ритма (р<0,05). Лечение карведилолом в течение 4 недель также позволяет достоверно уменьшить выраженность желудочковых нарушений ритма, в том числе снижает частоту желудочковых экстрасистол высоких градаций. Парные экстрасистолы исходно выявлялись в 9\% случаев, полиморфные - у 26\% больных, через 4 недели исследования их частота составила 4\% и 14\% соответственно (p<0,05). Также полностью были устранены пробежки желудочковой тахикардии.

По результатам исследования увеличенная продолжительность QTc (> 440 мс) была выявлена у $22 \%$ пациентов с СД 2-го типа. Прием карведилола сопровождался достоверным снижением средней продолжительности интервала QT с $424(388 ; 432)$ мс до 401 (366; 410) мс и дисперсии интервала QT с 44 (38; 46$)$ мс до $32(28 ; 36)$ мс.

Выводы: терапия карведилолом позволяет нормализовать показатели чСС и ее циркадный индекс, значимо уменьшает частоту суправентрикулярных и вентрикулярных экстрасистол, неустойчивых пароксизмов фибрилляции предсердий, пробежек желудочковой тахикардии у больных с СД 2 типа, уменьшает длительность интервала Q-T. 